\title{
UPAYA PENINGKATAN KUALITAS PELAYANAN PADA PERUSAHAAN DAERAH AIR MINUM (PDAM) KOTA SEMARANG
}

\author{
Tommy Akmal Syah \\ Dian Triyani
}

Fakultas Ekonomi_Jurusan Manajemen_Universitas Semarang

Diterima: November 2018. Disetujui: Desember 2018. Dipublikasikan: Januari 2019

\begin{abstract}
This study aims to improve the quality of service of the Regional Water Company (PDAM) of Semarang City. Due to the fact that in the last few months the people of Semarang City, especially PDAM customers, complained about the crisis of clean water from the PDAM, which included a small amount of water discharge, sometimes dirty and smelly water and water that often even for days did not flow.

This research was conducted with qualitative research methods with direct interviews with 6 informants namely 4 PDAM customers and 2 PDAM employees in Semarang City. By aiming to get valid and balanced information between customers directly with PDAM employees to get the best research results / solutions.

The results of this study indicate that most PDAM customers complained about the frequent flow of PDAM water. And from the employees, the PDAM also acknowledged that the water discharge in the Water Treatment Plant (IPA) in Kudu and in Kaligarang had a water crisis due to the long summer. Factors that affect the quality of good service include Quality, Services, Services, Regional Companies, Service Support Factors, service inhibiting factors, Workloads, Work Results and Work Systems. Therefore the PDAM provides a solution by making 3 Drinking Water Treatment Systems (SPAM) which are expected to increase the supply of clean water to PDAM customers.
\end{abstract}

Keywords: Quality, Service, PDAM

ABSTRAK
Penelitian ini bertujuan untuk meningkatkan kualitas pelayanan Perusahaan Daerah Air Minum (PDAM) Kota Semarang. Dikarenakan dalam beberapa bulan terakhir masyarakat Kota Semarang Khususnya pelanggan PDAM mengeluhkan tentang krisis air bersih dari PDAM yang diantara nya debit air yang sedikit, air yang terkadang kotor dan berbau serta air yang sering bahkan berhari-hari tidak mengalir.

Penelitian ini dilakukan dengan metode penelitian kualitatif dengan wawancara langsung terhadap 6 Informan yaitu 4 pelanggan PDAM dan 2 karyawan PDAM Kota Semarang. Dengan bertujuan agar mendapatkan informasi yang valid dan berimbang antara pelanggan langsung dengan karyawan PDAM utuk mendapatkan hasil penelitian / solusi yang terbaik.

Hasil Penelitian ini menunjukkan bahwa sebagian besar pelanggan PDAM mengeluhkan tentang sering nya air PDAM yang tidak mengalir. Dan dari pihak karyawan PDAM pun mengakui bahwa debit air di Instalasi Pengolahan Air (IPA) di Kudu dan di Kaligarang mengalami krisis air dikarenakan musim panas yang panjang. Faktor yang mempengaruhi kualitas pelayanan yang baik diantaranya adalah Kualitas, Jasa, Pelayanan, Perusahaan Daerah, Faktor Pendukung Pelayanan, Faktor penghambat pelayanan, Beban Kerja, Hasil Kerja dan Sistem Kerja. Oleh karena itu PDAM memberikan solusi dengan membuat 3 Sistem Pengolahan Air Minum (SPAM) yang diharapkan dapat menambah pasokan air bersih ke pelanggan PDAM.

Kata Kunci : Kualitas, Pelayanan, PDAM 


\section{Latar belakang masalah}

Bagi sebuah perusahaan, kualitas pelayanan merupakan suatu hal yang sangat penting. Dengan memberikan kualitas pelayanan yang baik, maka akan menghasilkan output yang baik pula bagi perusahaan. Salah satu cara yang dilakukan sebuah instansi pemerintah atau dalam hal ini Perusahaan Daerah dalam meningkatkan kepuasan pelanggan adalah memberikan pelayanan yang maksimal kepada semua pelanggan yang bertujuan untuk memberikan pelayanan prima terhadap semua pelanggan perusahaan. Kualitas pelayanan adalah sebuah tolak ukur dari pada sebuah kinerja perusahaan dalam memberikan pelayanan yang baik terhadap pelanggannya. Dengan terciptanya pelayanan yang baik dalam perusahaan menandakan bahwa perusahaan tersebut memiliki iklim kerja yang positif. Hal ini disebabkan karena adanya karyawan dan usaha maksimal yang memiliki keterikatan yang baik dengan perusahaan tempat ia bekerja. Maka mereka akan memiliki antusiasme yang besar untuk bekerja, maka mereka akan memiliki antusiasme yang besar untuk memberikan kualitas pelayanan yang tinggi dan baik, bahkanterkadang jauh melamapaui tugas pokok yang tertuang dalam Standart Operasional Perusahaan (SOP) kerja tiap karyawan.

Konsep kualitas secara luas tidak hanya menekankan pada aspek hasil tetapi juga kualitas manusia dan kualitas prosesnya. Bahkan Stephen Uselac menegaskan bahwa kualitas bukan hanya mencakup produk dan jasa, tetapi juga meliputi proses, linkungan dan manusia.Meskipun tidak ada defenisi mengenai kualitas yang diterima secara universal, dari defenisi-defenisi yang ada terdapat beberapa kesamaan, yaitu dalam elemen-elemen yaitu Kualitas meliputi usaha mamenuhi atau melebihi harapan pelanggan,kualitas mencakup produk, jasa, manusia, proses dan lingkungan,kualitas merupakan kondisi yang selalu berubah ( misalnya apa yang dianggap merupakan kualitas saat ini mungkin dianggap kurang berkualitas pada mendatang).Kualitas Produk adalah kemampuan suatu produk untuk melaksanakan fungsinya meliputi, daya tahan, kehandalan, kemudahan operasi dan meningkatkan akurasi, serta atribut berharga lainnya. Untuk meningkatkan kualitas produk perusahaan dapat melaksanakan program “Total Quality Management (TQM)". Selain mengurangi kerusakan produk, tujuan utama adalah untuk meningkatkan kualitas nilai total pelanggan.Kualitas atau mutu adalah tingkat baik buruknya atau taraf atau derajat sesuatu. Istilah ini banyak digunakan 
dalam dalam bisnis, rekayasa, dan manufaktur dalam kaitannya dengan teknikdan konsep untuk memperbaiki kualitas produk atau jasa yang dihasilkan, seperti Six Sigma, TQM, Kaizen, dll.

Air sebagai sumber kehidupan mahluk hidup terutama manusia yang berkembang dengan berbagai macam kebutuhan dasar manusia (basic human need). Air menjadi kebutuhan primer yang diperlukan untuk kebutuhan sehari-hari seperti minum, masak, mandi sampai kebutuhan pengolahan industri, sehingga fungsi air tidak hanya terbatas untuk menjalankan fungsi ekonomi saja, namun juga sebagai fungsi sosial. Masyarakat memang sudah dimanjakan dengan air yang melimpah karena Negara kita berada di wilayah tropika basah yang curah hujannya cukup tinggi. Akan tetapi masyarakat banyak yang tidak tahu kalau Negara Indonesia termasuk salah satu negara yang terancam krisis air pada sepuluh tahun kedepan. Hal ini disebabkan karena semakin meluas dan parahnya kerusakan DAS (Daerah Aliran Sungai),sehingga kemampuan menyerap, menyimpan dan melepas air menjadi sangat rendah. Banjir di musim hujan dan kekeringan di musim kemarau adalah indikator yang sangat nyata. Selain itu pertambahan penduduk, penebangan liar, dan makin tipisnya lahan untuk menampung air merupakan ancaman serius ketersediaan air di masa sekarang dan masa depan. Mengingat air merupakan kebutuhan pokok dalam kehidupan sehari-hari, air memiliki peranan penting untuk mendukung kemakmuran dan kesejahteraan masyarakat. Tersedianya air yang memadai akan mendorong perkembangan sector pembangunan di masyarakat. Program yang dilakukanoleh PDAM baik didaerah perkotaan maupun dipedesaan mempunyai tujuan untuk memberikan pelayanan pada masyarakat mendapatkan air bersih yang sehat dan memadai untuk keperluan rumah tangga maupun industry untuk menunjang perkembangan ekonomi dan derajat kesehatan penduduk. Fungsi sosial maupun fungsi ekonomi yang dimiliki air dalam rangka memenuhi kebutuhan sehari-hari merupakan hal yang penting untuk diperhatikan, karena seiring dengan pertambahan penduduk maka kebutuhan air tidak dapat dipungkiri akan semakin meningkat. Maka dalam menyikapi hal tersebut pemerintah mengelola sebuah perusahaan milik Negara yaitu Perusahaan Daerah Air Minum yang biasanya lebih dikenal sebagai PDAM. PDAM tersebar diseluruh daerah dan kota di Indonesia termasuk Kota Semarang yang merupakan perusahaan milik pemerintah Kota Semarang.PDAM di Kota Semarang diberi nama PDAM Tirta Moedal. 
Program yang dilakukan oleh PDAM baik didaerah perkotaan maupun dipedesaan mempunyai tujuan untuk memberikan pelayanan pada masyarakat mendapatkan air bersih yang sehat dan memadai untuk keperluan rumah tangga maupun industri untuk menunjang perkembangan ekonomi dan derajat kesehatan penduduk.

Kualitas sebagaimana diinterpretasikan ISO 9000 merupakan perpaduan antara sifat dan karakteristik yang menentukan sejauh mana keluaran dapat memenuhi persyaratan kebutuhan pelanggan.Pelanggan yang menentukan dan menilai sampai seberapa jauh sifat dan karakteristik itu memenuhi kebutuhannya. Dalam hal pelayanan tentunya PDAM salah satu perusahaan yang wajib memberikan pelayanan yang baik kepada pelanggan mengingat PDAM penyuplai utama air bersih perkotaan. Menurut Fandy Tjiptono (2012) mendefinisikan pelayanan (service) biasa dipandang sebagai sebuah sistem yang terdiri atas dua komponen utama, yakni service operations yang kerap kali tidak tampak atau tidak diketahui keberadaannya oleh pelanggan (back office atau backstage) dan service delivery yang biasanya tampak (visible) atau diketahui pelanggan (sering disebut pula front office atau frontstage). Menurut Fandy Tjiptono (2012) mendefinisikan kualitas pelayanan adalah ukuran seberapa bagus tingkat layanan yang diberikan mampu sesuai dengan ekspektasi pelanggan. Definisi lain kualitas pelayanan menurut Wyckof dalam Lovelock yang dikutipoleh Fandy Tjiptono(2012) merupakan tingkat keunggulan (excellence) yang diharapkan dan pengendalian atas keunggulan tersebut untuk memenuhi keinginan pelanggan.

Sebagai salah satu perusahaan publik yang ada didaerah, PDAM pelayanan sangat diperlukan kehadirannya bagi masyarakat, demikian pula halnya pentingnya keberadaan PDAM di Kota Semarang. PDAM Tirta Moedal mengambil sumber air dari Sungai Banjir Kanal Barat, sungai Jatibarang dan Sumber air Kudu (Genuk). Selain itu, PDAM Tirta Moedal memperoleh bahan baku dari air tanah. Untuk saat ini pelayanan yang diberikan oleh PDAM kepada masyarakat antara lain; pemasangan baru, perbaikan dan pembayaran rekening serta pelayanan air itu sendiri. PDAM Tirta Moedal Kota Semarang melayani 166215 pelanggan terhitung sampai bulan Desember 2016. 
Gambar.1.

Keluhan Pelanggan PDAM Tirta Moedal

Bulan Januari - Juni 2018

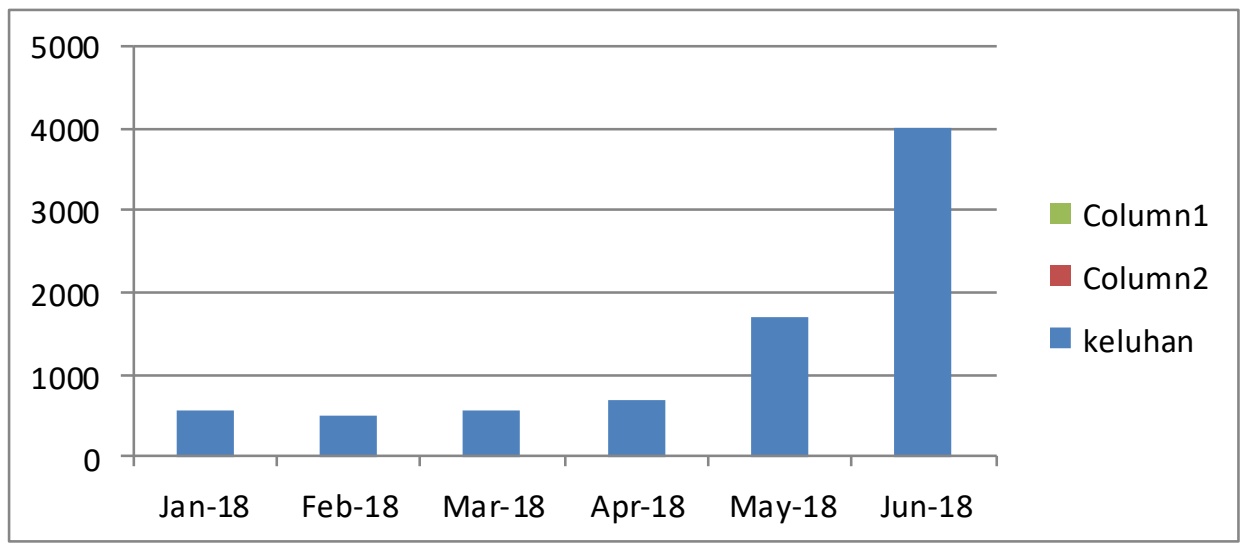

Sumber : data Litbang PDAM Kota Semarang 2018

Berdasarkan data keluhan pelanggan pdam diatas terjadi kenaikan signifikan pada bulan mei dan juni 2018. Pada bulan Januari tahun 2018 keluhan pelanggan PDAM terhadap kualitas pelayanan PDAM telah terjadi sebanyak 567 keluhan. Pada bulan Februari 2018 terdapat keluhan sebanyak 499 laporan. Bulan Maret naik kembali menjadi 542 laporan keluhan, bulan April naik hingga 699 keluhan. Di bulan Mei 2018 naik hampir 3x lipat menjadi 1669 laporan keluhan masyarakat dan di bulan Juni 2018 terjadi kenaikan 3x lipat lebih dari bulan mei lalu menjadi 4003 keluhan masyarakat Kota Semarang. Ini menjadi pertanda bahwa kualitas pelayanan PDAM Kota Semarang di awal tahun 2018 sangat tidak memuaskan karena banyaknya laporan keluhan Masyarakat terhadap Kualitas Pelayanan yang diberikan PDAM Kota Semarang.

Harapan PDAM untuk memenuhi kebutuhan masyarakat ternyata belum sejalan dengan kenyataan yang ada pada perilaku pelanggan dalam menyikapi pelayanan yang telah diberikan oleh PDAM. Masih banyak para pelanggan Perusahaan Daerah Air Minum (PDAM), mengeluhkan pelayanan yang diberikan oleh pihak PDAM. Menurut sumber dari harian Suara Merdeka ( kamis 19 april 2018 ) bahwa konsumen PDAM mengeluhkan pelayanan PDAM diantaranya yaitu " akhir akhir ini air PDAM di Gemah Pedurungan sering tidak mengalir dan keruh. Sebagai konsumen, kami sangat kecewa 
dengan kinerja PDAM. Pelayanan seyogyanya semakin baik bukan sebaliknya” . dalam keluhan masyarakat yang sama terdapat laporan " PDAM di Perumahan Medoho City Park sudah tidak mengalir dalam waktu semiggu".

Sementara itu dalam laporan lain menyebutkan bahwa seplai air PDAM macet lagi khusus nya di wilayah Semarang Timur. Hal ini dikarenakan pasokan air dari Bendung Klambu ke Instalasi Pengolahan Air (IPA) Kudu di Jl Kramat Raya, Kudu, Kecamatan Genuk, terganggu. Evaluasi di bendung Klambu pada hari minggu (5/6) pagi berkisar 15,53 meter. Realisasi air yang dapat diberikan untuk intake Saluran Air Baku (SAB) ke IPA Kudu sebanyak 300 liter/detik, dari kebutuhan minimal 900 liter /detik. (Harian Suara Merdeka senin 7 Mei 2018)

Keluhan paling banyak yaitu karena minimnya pasokan air ke banyak wilayah. Tidak hanya di Semarang timur saja yang minim tetapi juga terdapat pada daerah seperti Gunung Pati, Semarang Utara, Semarang Tengah, Mijen dan hampir seluruhnya, merata di wilayah Kota Semarang. Pemerintah Kota Semarang langsung menyidak salah satu Instalasi Pengolahan Air (IPA) di Kudu, Genuk. Dan walikota Semarang (Hendrar Prihadi) langsung mengecek sistem distribusi air PDAM Kota Semarang karena sudah 2 minggu berturut-turut distribusi Air PDAM tidak mengalir ke mayoritaas penduduk Semarang. Dan beliau menuturkan bahwa evaluasi akan terus dilakukan. ( instagram @ hendrarprihadi 7 Mei 2018 ).

Terhadap keluhan yang diberikan oleh pelanggan, Pihak PDAM menggolongkan keluhan tersebut menjadi dua sesuai dengan beratnya masalah, yaitu; keluhan yang dapat langsung ditangani dan pending (menunggu). Keluhan yang langsung dapat ditangani PDAM misalnya kebocoran pipa pelanggan. Jika keluhan yang harus menunggu atau pending commit to user terjadi karena memerlukan waktu beberapa hari untuk melakukan pengecekan terlebih dahulu untuk mengetahui sumber permasalahannya. (Sumber : koran Suara Merdeka edisi tanggal 8 mei 2018)

PDAM sebagai public service dirancang dan diselenggarakan untuk memenuhi kebutuhan masyarakat. Dengan membangun kinerja pelayanan publik yang baik, sesungguhnya perusahaan bisa membangun hubungan baikdengan masyarakat dan legitimasinya dimata publik. Walaupun begitu anggapan masyarakat tentang PDAM selalu memperoleh keuntungan tidak memikirkan masyarakat sudah terlanjur melekat. 
Sehingga perlu dilakukan perubahan-perubahan supaya masyarakat mengetahui kondisi sebenarnya yang dihadapi PDAM.

Salah satu yang memperburuk krisis sampai saat ini adalah buruknya kepercayaan masyarakat terhadap aparatur pemerintah terutama di sektor pelayanan publik. Sehingga muncul sikap, anggapan dan penilaian terhadap pemerintahan. Misalnya kesan bahwa birokrasi adalah prosedur yang berbelit-belit dan mempersulit urusan. Adanya nepotisme, kolusi dan korupsi dalam sektor pelayanan publik. Bahkan dalam pelayanan publik sering muncul penawaran-penawaran yang dapat mempermudah suatu proses yang seharusnya melalui berbagai proses tetapi dipermudah.

Seiring dengan adanya globalisasi ini, masalah kualitas merupakan salah satu bagian penting dan sangat perlu mendapat perhatian yang serius bagi setiap perusahaan untuk tetap bisa bertahan dalam lingkungan bisnis. Masyarakat sebagai pelanggan PDAM menuntut kualitas pelayanan yang cepat dan hasil produksi yang baik. Sebagai pelanggan PDAM, masyarakat akan merasakan kejenuhan bila hasil produksi, pelayanan publik tidak memuaskan sehingga pelanggan akan memilih jalan keluar lain seperti pemasangan air sumur. Hal tersebut dapat berdampak pada penurunan jumlah pelanggan.

PDAM merupakan perusahaan yang dikelola oleh pemerintah daerah yang dalam pengoperasiannya sebagai badan pelayanan masyarakat. PDAM sebagai organisasi sektor publik mengutamakan pemenuhan kepuasan masyarakat melalui penyediaan barang dan pelayanan publik yang berkualitas dengan harga yang terjangkau. Dalam rangka memenuhi kepuasan pelanggan PDAM harus mampu mengidentifikasi faktor-faktor yang mempengaruhi kepuasan pelanggan kemudian membuat ukuran-ukuran kepuasan tersebut, karena tujuan organisasi sektor publik adalah untuk menciptakan kesejahteran masyarakat (welfare society).

Dengan adanya langkah perbaikan kualitas maka suatu perusahaan dapat menyelenggarakan kearah yang lebih baik (good governance). Good governance oleh LAN mendefinisikan dengan dua pengertian yaitu, pertama: nilai-nilai yang menjunjung tinggi kehendak rakyat dan nilai-nilai yang dapat meningkatkan kemampuan rakyat dalam mencapai tujuan nasional, kemandirian, pembangunan berkelanjutan dan keadilan sosial dan; kedua:aspek-aspek fungsional dari pemerintahan yang efisien dan efektif dalam pelaksanaan tugasnya untuk mencapai tujuan yang dimaksud. 
Sebagian masyarakat Kota Semarang sendiri memandang bahwa pelayanan PDAM dianggap belum bisa memberikan hasil produksi yang baik. Karena masyarakat lebih cenderung melihat pada hasil akhir produksi. Munculnya berbagai keluhan dan sorotan publik terhadap pelayanan yang dilakukan oleh PDAM Tirta Moedal merupakan tantangan bagi instansi tersebut untuk meningkatkan kualitasnya. Untuk mengetahui kualitas pelayanan PDAM, maka dari itu itu penulis tertarik untuk mengadakan penelitian mengenai Kualitas Pelayanan Perusahaan Daerah Air Minum (PDAM) Tirta Moedal Kota Semarang.

Berdasarkan latar belakang permasalahan, maka judul yang diambil dalam penelitian ini adalah : "UPAYA PENINGKATAN KUALITAS PELAYANAN PADA PERUSAHAAN DAERAH AIR MINUM (PDAM) KOTA SEMARANG”.

\section{Perumusan Masalah}

Berpijak pada uraian latar belakang dan pengamatan pada Perusahaan Daerah Air Minum (PDAM) Kota Semarang yang merupakan perusahaan daerah Kota Semarang yang bergerak di bidang pelayanan air bersih adalah perusahaan mengalami penurunan kualitas dalam pelayanan kepada pelanggan air bersih PDAM Kota Semarang dengan ditandai oleh banyaknya laporan keluhan masyarakat tentang kualitas pelayanan perusahaan yang menurun.

Sehubungan dengan latar belakang pemikiran yang telah diuraikan diatas, maka bisa dirumuskan masalah penelitian adalah bagaimana PDAM dapat menaikkan atau meningkatkan kualitas pelayanan sehingga keluhan pelanggan menurun ?.

\section{Pertanyaan Penelitian}

Pertanyaan penelitian ini adalah :

1. Faktor apa sajakah yang menjadi masalah dalam Kualitas Pelayanan di Perusahaan Daerah Air Minum (PDAM) Kota Semarang?

2. Bagaimana solusi dari Perusahaan Daeraah Air Minum (PDAM) Kota Semarang untuk mengatasi keluhan Masyarakat Kota Semarang terhadap Kualitas Pelayanan yang diberikan? 


\section{Gambar 2.}

Alur penelitian

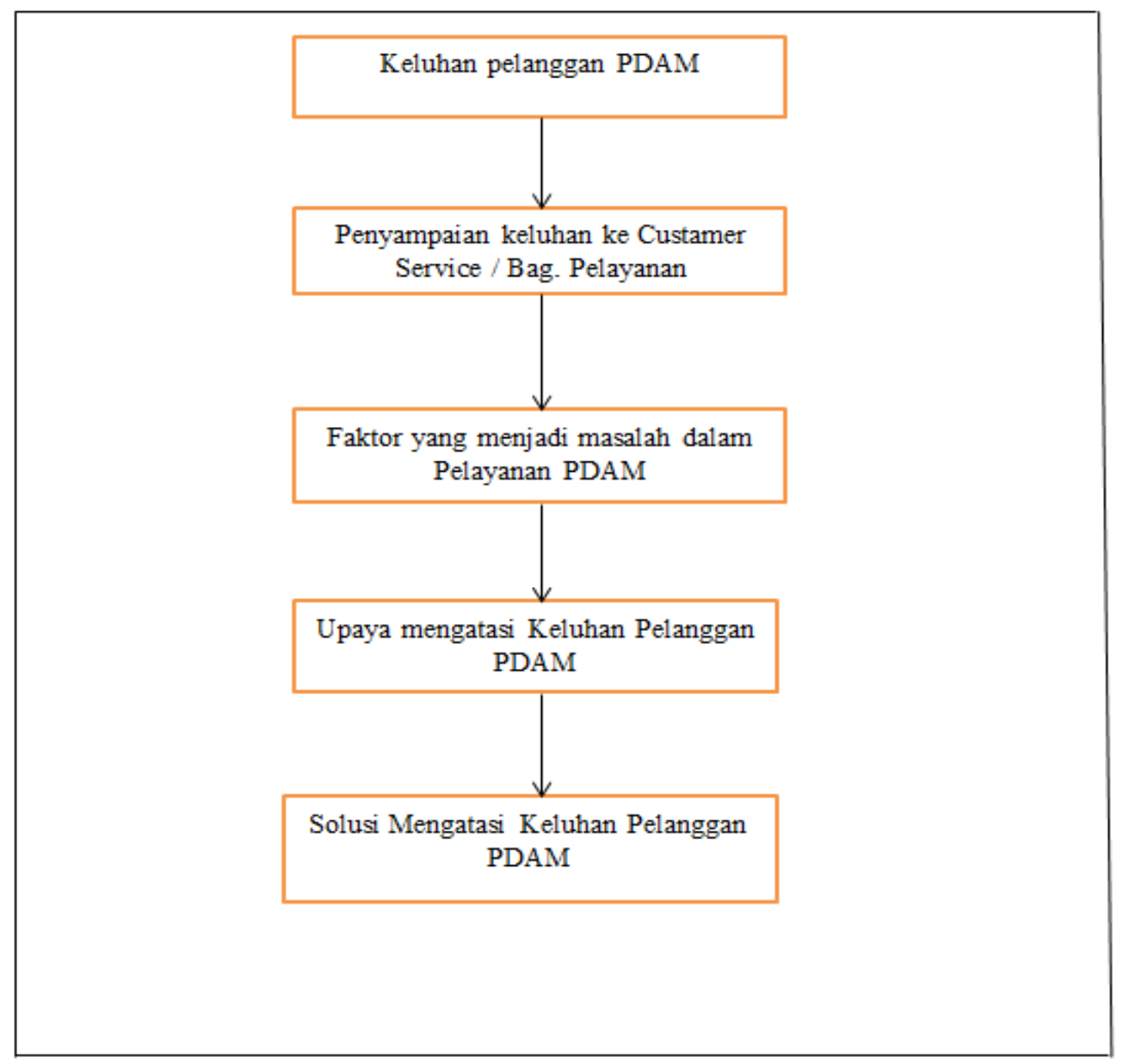

\section{Jenis Penelitian}

Dalam penelitian ini, penulis menggunakan jenis penelitian deskriptif dengan jenis data kualitatif, sebab penelitian ini berusaha untuk menjelaskan suatu fakta atau realita fenomena sosial tertentu sebagaimana adanya dan memberikan gambaran secara objektif tentang keadaan atau permasalahan yang mungkin dihadapi. Ini sesuai dengan jenis penelitian yang dimaksudkan untuk memberikan gambaran mengenai kualitas pelayanan Perusahaan Daerah Air Minum (PDAM) Tirta Moedal Kota Semarang, maka bentuk penelitian deskriptif yang memaparkan, menerangkan, menggambarkan, dan melukiskan serta menafsirkan dan menganalisis data dengan jenis data kualitatif yang ada merupakan bentuk penelitian yang sesuai. 


\section{Lokasi Penelitian}

Lokasi penelitian ini dilakukan di kanor pusat Perusahaan Daerah Air Minum (PDAM) di jalan Kelud Raya Kota Semarang. Penulis mengambil lokasi penelitian di Perusahaan Daerah Air Minum karena perusahaan tersebut merupakan merupakan perusahaan yang bertanggung jawab dalam memberikan dan menyediakan pelayanan air bersih dan air minum di Kota Semarang. Di situ pula kantor pusat perusahaan air minum yang memberikan jasa pelayanan dan karena masih adanya simpang siur di masyarakat tentang kualitas PDAM.

\section{Sumber Data dan Pemilihan Informan}

Dalam penelitian kualitatif posisi sumber data manusia (narasumber) sangat penting perannya sebagai individu yang memiliki informasinya. Peneliti dan narasumber disini memiliki posisi yang sama dan narasumber bukan sekedar memberikan tanggapan pada yang diminta peneliti, tetapi ia lebih memilih arah dan selera dalam menyajikan informasi yang ia miliki. (H.B. Sutopo, 2002:50)

Adapun sample atau informan dalam penelitian ini adalah orang orang yang benar benar mengerti dan mengalami dampak daripada menurunnya Kualitas pelayanan Perusahaan Daerah Air Minum (PDAM) Kota Semarang. Diantaranya yaitu ada sebagian daripada karyawan PDAM itu sendiri sebagai petugas dan Masyarakat umum yang merasakan dampak dariapda krisis pelayanan air di PDAM kota Semarang.

\section{Pembahasan}

Berdasarkan pola yang ada, peneliti menemukan temuan-temuan konsep atau variabel yang muncul dari hasil wawancara yang berkenaan dengan Upaya Peningkatkan Kualitas Pelayanan di Perusahaan Daerah Air Minum Tirta Moedal ( PDAM ) Kota Semarang yang telah peneliti lakukan. Adapun variabel-variabel tersebut adalah sebagai berikut : 


\section{Kualitas}

Goetsch \& Davis (dalam Fandy Tjiptono \& Gregorius Chandra 2005 : 110), kualitas adalah kondisi dinamis yang berhubungan dengan produk,jasa, sumber daya manusia, proses dan lingkungan yang memenuhi atau melebihi harapan pelanggan. Dari definisi tersebut dapat disimpulkan ada beberapa elemen yang sama mengenai definisi kualitas, yaitu :

1. Kualitas meliputi usaha untuk memenuhi atau melebihi harapan pelanggan.

2. Kualitas mencakup produk, jasa, manusia, proses, dan lingkungan. Kualitas merupakan kondisi yang selalu berubah

Kualitas adalah sebuah kata bagi penyedia jasa merupakan sesuatu yang harus dikerjakan dengan baik. Aplikasi kualitas sebagai sifat dari penampilan produk barang atau jasa merupakan bagian utama strategi perusahaan dalam rangka meraih keunggulan yang berkesinambungan, baik sebagai pemimpin pasar ataupun sebagai strategi untuk terus tumbuh. Maka dari itu, yang perlu diperhatikan dalam pengembangan dan peningkatan adalah sistem kualitas yang meliputi, perencanaan, pengendalian, dan perbaikan kualitas.

Di Perusahaan Daerah Air Minum (PDAM) Kota Semarang pada tahun ini belum memberikan kualitas yang memuaskan, bisa dilihat dari grafik keluhan pelanggan PDAM dibawah ini :

Gambar 3

Grafik Keluhan Pelanggan PDAM

Tirta Moedal Bulan Januari - Juni 2018

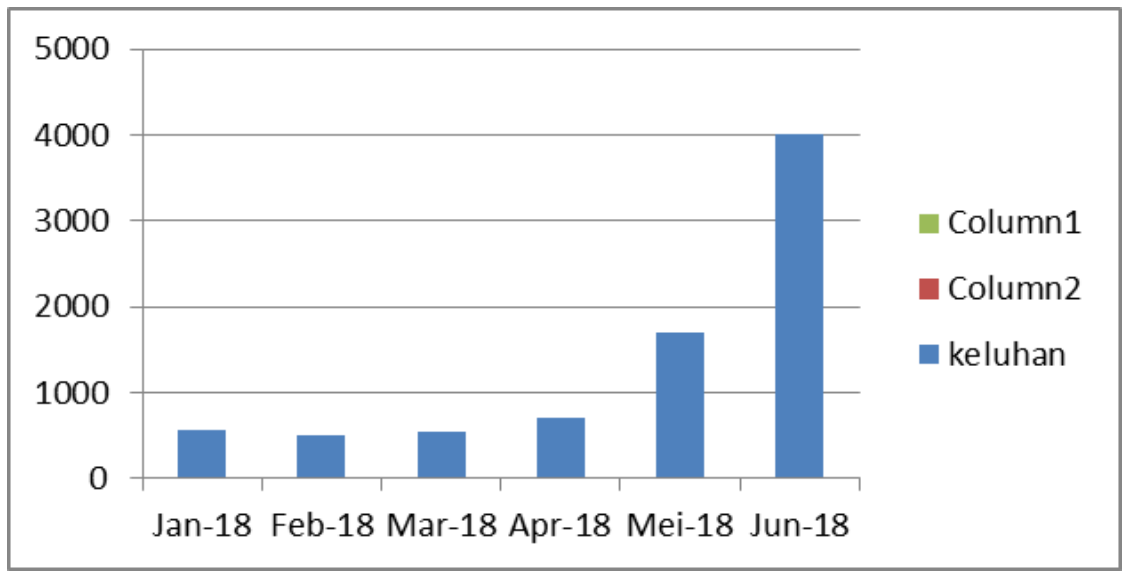

Sumber : Data Litbang PDAM Kota Semarang tahun 2018 


\section{Pelayanan}

Pelayanan menurut Ratminto dan Atik (dalam Modul Manajemen Pelayanan, 2006) adalah suatu proses bantuan kepada orang lain dengan cara-cara tertentu yang memerlukan kepekaan dan hubungan interpersonal agar terciptanya kepuasan dan kebehasilan. Setiap pelayanan menghasilkan (produk), baik berupa barang dan jasa. Hasil pelayanan berupa jasa tidak dapat diinventarisasi, ditumpuk, atau digudangkan melainkan hasil tersebut diserahkan secara langsung kepada pelanggan atau konsumen. Dalam hal pelayanan diberikan dengan tidak optimal maka pelayanan tidak dapat diulangi, karena pelayanan diberikan secara langsung kepada pelanggan. Pelanggan adalah semua orang yang menuntut kita atau perusahaan untuk memenuhi standar kualitas tertentu, dan karena itu akan memberikan pengaruh pada perfomance kita atau perusahaan.

Masyarakat pengguna air PDAM khususnya Pelanggan PDAM Kota Semarang ingin pelayanan PDAM terkait masalah air bersih selalu di tingkatkan. Dalam temuan wawancara banyak dikeluhkan di sektor seringnya air mati terutama di musim kemarau. Dalam hal ini PDAM harus memiliki tambahan sumber air untuk mengantisipasi minimnya debit air / pasokan air ke pelanggan-pelanggan PDAM agar air tidak sering mati. Karena air mati tidak hanya berjam jam saja, tapi bisa sampai berhari-hari.

\section{Kualitas Pelayanan (Jasa)}

Dalam jurnalnya, Tracey S. Dagger, Jillian C. Sweeney, Laster W. Johnson (2007) mengemukakan Persepsi kualitas pelayanan didefinisikan secara umum sebagai penilaian atau kesan konsumen terhadap kebaikan atau superioritas suatu hal. Penilaian ini selalu menggambarkan ketidaksesuaian antara pelayanan yang diharapkan pelanggan dan kinerja pelayanan sebenarnya. Agar pelayanan memiliki kualitas dan memberikan kepuasan kepada pelanggan mereka, maka perusahaan harus memperhatikan berbagai dimensi yang dapat menciptakan dan meningkatkan kualitas pelayanannya. Jasa menurut Kotler dan Keller yang diterjemahkan oleh Bob Sabran (2012) jasa atau layanan adalah semua tindakan atau kinerja yang dapat ditawarkan satu pihak kepada pihak lain yang pada intinya tidak berwujud dan tidak menghasilkan kepemilikan apapun produksinya dapat atau tidak terkait dengan produk fisik.

PDAM dalam jasa nyatelah memberikan jasa pengolahan air minum yang baik, tetapi dalam temuan beberapa narasumber bahwa air masih berbau, dan berwarna (tidak 
jernih). Hal ini harus sangat diperhatikan karena dapat menyebabkan penyakit bila air tersebut dikonsumsi oleh masyarakat.

\section{Perusahaan Daerah}

UU No.5 tahun 1962 tentang perusahaan daerah menyebutkan bahwa sifat perusahaan daerah diantaranya adalah memberi jasa, penyelenggaraan kemanfaatan umum, dan memupuk pendapatan. Perusahaan Daerah adalah semua perusahaan yang didirikan berdasarkan UU No.5/1962 yang seluruh atau sebagian modalnya merupakan kekayaan daerah yang dipisahkan, kecuali jika ditentukan lain dengan atau berdasarkan Undang-Undang.

PDAM yang merupakan lembaga pemerintah berbentuk perusahaan daerah memiliki sifat yang dijelaskan dalam pasal5 UU No. 5 / 1962, sebagai berikut:

1. Perusahaan Daerah adalah satu kesatuan produksi yang bersifat:
a. Memberi jasa
b. Menyelenggarakan kemanfaatan umum
c. Memupuk pendapatan

2. Tujuan Perusahaan Daerah adalah untuk turut serta melaksanakan pembangunan daerah khususnya dan pembangunan ekonomi nasional pada umumnya untuk memenuhi kebutuhan rakyat dengan mengutamakan industrialisasi dan ketentraman serta ketenangan kerja dalam perusahaan, menuju masyarakat adil dan makmur.

PDAM Kota Semarang adalah perusahaan daerah milik Pemerintah Kota Semarang. PDAM wajib memberi jasa, penyelenggaraan kemanfaatan umum, dan memupuk pendapatan. Perusahaan Daerah adalah semua perusahaan yang didirikan berdasarkan UU No.5/1962. Tetapi Perusahaan Daerah Khususnya PDAM juga wajib memperhatikan Kualitas Pelayanan kepada pelanggan-pelanggan nya agar tidak menjadi sebuah masalah yang saat ini sedang dihadapi PDAM. Dengan melalui program pembangunan Sistem Penyedia Air Minum (SPAM) diharapkan dapat mewujudkan tugas pokok Perusahaan daerah dengan memberi jasa, penyelenggaraan kemanfaatan umum, dan memupuk pendapatan di Kota Semarang. 


\section{Faktor Pendukung Pelayanan}

Pelayanan yang baik tidak terlepas dari faktor-faktor pendukung, baik itu fasilitas fisik maupun sumber daya manusia. Beberapa faktor pendukung tersebut, yaitu : (H.A.S. Moenir, 2000)

1. Faktor kesadaran.

Adanya kesadaran dapat membawa seseorang kepada keikhlasan dan kesungguhan dalam menjalankan suatu tugas baik tertulis maupun tidak tertulis, mengikat semua orang dalam organisasi kerja. Oleh karena itu, dengan adanya kesadaran pada pegawai atau petugas diharapkan mereka melaksanakan tugas dengan keikhlasan, kesungguhan dan kedisiplinan.

2. Faktor aturan.

Dalam organisasi kerja aturan dibuat oleh manajemen sebagai pihak yang berwenang dan mengatur segala sesuatu yang ada di organisasi tersebut. Setiap aturan menyangkut terhadap manusia baik sebagai subyek aturan, artinya mereka yang membuat, menjalankan dan mengawasi pelaksanaan aturan maupunmanusia sebagai obyek aturan, yaitu mereka yang dikenai oleh aturan itu.

3. Faktor Organisasi.

Dalam organisasi pelayanan, organisasi tidak semata-mata dilihat sebagai perwujudan susunan organisasi, melainkan lebih banyak pengaturan dan mekanisme kerjanya yang harus mampu menghasilkan pelayanan yang memadai. Karena organisasi adalah mekanisme maka perlu adanya sarana pendukung yang berfungsi memperlancar mekanisme itu, yaitu sistem,prosedur, dan metode

4. Faktor Pendapatan.

Pendapatan adalah seluruh penerimaan seseorang sebagai imbalan atas tenaga atau pikiran yang telah dicurahkan untuk orang lain atau badan/ organisasi dalam jangka waktu tertentu. Pada dasarnya pendapatan harus dapat memenuhi kebutuhan hidup baik untuk dirinya maupun untuk keluarga. Pendapatan pegawai yang tidak mencukupi kebutuhan hidup meskipun secara minimal akan mengakibatkan pegawai berusaha mencaritambahan pendapatan dengan cara menjual jasa pelayanan. 
5. Faktor kemampuan dan ketrampilan.

Dengan kemampuan dan ketrampilan yang memadai maka pelaksanaan tugas / pekerjaan dapat dilakukan dengan baik,cepat dan memenuhi keinginan semua pihak, baik manajemen itu sendiri maupun masyarakat.

6. Faktor sarana pelayanan.

Sarana pelayanan yang dimaksud di sini adalah sejenis peralatan, perlengkapan kerja dan fasilitas lain yang berfungsi sebagai alat utama/pembantu dalam pelaksanaan pekerjaan dan juga berfungsi sosial dalam rangka kepentingan orang-orang yang sedang berhubungan dengan organisasi kerja itu.

PDAM Kota Semarang harus memperhatikan faktor faktor tersebut agar keluhan masyarakat terhadap kualitas pelayanan PDAM dapat ditingkatkan. Terutama pembangunan IPA (Instalasi Pengolahan Air) dan pembangunan SPAM di 3 lokasi di Kota Semarang. Karena 2 cara tersebut adalah solusi terbaik untuk mengatasi minimnya pasokan air ke pelanggan pelanggan PDAM Kota Semarang.

\section{Faktor Penghambat Pelayanan Umum}

Persepsi pelanggan terhadap kualitas pelayanan yang diberikan oleh perusahaan maupun instansi pelayanan umum merupakan dasar usaha peningkatan kualitas pelayanan. Adapun faktor-faktor yang menghambat kualitas layanan dapat diidentifikasikan sebagai berikut : (Zulian Yamit, 2001)

1. Kurang otoritas yang diberikan pada bawahan.

2. Terlalu birokrasi sehingga lambat dalam menanggapi keluhan konsumen.

3. Bawahan tidak berani mengambil keputusan sebelum ada ijin dari atasan.

4. Petugas sering bertindak kaku dan tidak memberi jalan keluar yang baik.

5. Petugas sering tidak ada di tempat pada waktu jam kerja sehingga sulit untuk dihubungi.

6. Banyak interest pribadi.

7. Budaya tip.

8. Aturan main yang tidak terbuka dan tidak jelas.

9. Kurang profesional (kurang terampil dalam menguasai bidangnya).

10. Banyak instansi atau bagian lain yang terlibat.

11. Disiplin kerja sangat kurang dan tidak tepat waktu.

12. Tidak adanya keselarasan antar bagian dalam memberikan pelayanan. 
13. Kurang kontrol sehingga petugas agak "nakal".

14. Ada diskriminasi dalam memberikan pelayanan.

15. Belum ada Sistem informasi Manajemen (SIM) yang terintegrasi.

Keseluruhan faktor penghambat tersebut dapat dijadikan perusahaan sebagai alat untuk memperbaiki atau mengurangi kesenjangan yang terjadi antara perusahaan dan pelanggan.

Dari sekian banyak faktor penghambat pelayanan di PDAM Kota Semarang adalah panjang nya waktu musim kemarau yang ada di wilayah Kota Semarang yang berdampak pada kurang nya air yang diolah oleh PDAM sehingga pasokan air yang akan di distribusikan ke pelanggan PDAM menjadi berkurang. Dengan masalah tersebut maka disimpulkanlah pembangunan SPAM yang diharapkan dapat menambah pasokan air ke pelanggan PDAM agar saat musim kemarau tiba PDAM masih memiliki cadangan air bersih untuk disalurkan ke pelanggan PDAM Kota Semarang.

\section{Sistem Kerja}

Iwan irawan (2010) menyebutkan bahwa Sistem kerja adalah serangkaian dari beberapa pekerjaan yang berbeda kemudian dipadukan untuk menghasilkan suatu benda atau jasa yang menghasilkan pelanggan atau keuntungan perusahaan/organisasi. Sistem kerja melibatkan banyak faktor manusia dan adanya keterkaitan pola kerja manusia dengan alat atau mesin, faktor-faktor yang dikombinasikan antara manusia dan alat tersebut suatu prosedur atau tahapan kerja yang sudah tetap dan di dokumentasikan sehingga menghasilkan suatu sistem kerja yang konsisten dan dapat menghasilkan hasil kerja yang berkualitas. Semakin baik sistem kerja yang diterapkan dalam suatu perusahaan, semakin baik pula kualitas kerja yang dihasilkan, semakin baik kualitas kerja yang dihasilkan maka semakin baik pula kualitas pelayanan yang dihasilkan oleh PDAM Kota Semarang.

Sistem kerja di PDAM Kota Semarang sudah memenuhu syarat dan SOP dari Pemerintah Kota Semarang. Mengenai buruknya dan banyaknya keluhan yang ada disebabkan karena faktor alam dan panjangnya musim kemarau khususnya di Kota Semarang. Hasilnya debit air menurun, lalu pasokan air ke konsumen menjadi berkurang dan berujung beberapa daerah di Kota Semarang kekurangan air atau air mati. 


\section{Kualitas Hasil Kerja}

Sulistiyani dan Rosidah (2009) menyatakan bahwa kualitas pekerjaan merupakan bagian substansi yang tidak dapat diabaikan. Sementara Wirawan (2009) menyatakan bahwa kualitas melukiskan seberapa baik atau seberapa lengkap hasil harus dicapai. Dalam mengukur kinerja berdasarkan kualitas dari hasil, dilakukan identifikasi bagaimana pencapaian kualitas pekerjaan yang dilakukan artinya melihat mutu hasil kerja yang didasarkan pada standar yang didasarkan pada standar yang ditetapkan. Kualitas kerja diukur dengan melihat ketetapan ketelitian, kerapihan, dan keberhasilan hasil pekerjaan sesuai dengan standar kualitas yang diharapkan.hal ini yang perlu dicermati oleh karyawan PDAM Kota Semarang dalam bekerja. Dengan adanya masalah yang dihadapi oleh PDAM diharapkan para karyawan dapat meningkatkan pekerjaan di sektor Pengawasan, Penelitian dan Pengembangan (litbang) distribusi dan sektor sektor lain agar kualitas pelayanan PDAM dapat membaik dan masyarakat Kota Semarang tidak resah lagi terhadap masalah Air PDAM.

\section{Beban Kerja}

Beban kerja kualitatif, jika pekerja merasa tidak mampu melaksanakan tugas atau tugas tidak menggunakan keterampilan atau potensi dari pekerja. (Tulus Winarsunu, 2008) Beban kerja adalah sekumpulan atau sejumlah kegiatan yang harus diselesaikan oleh suatu unit organisasi atau pemegang jabatan dalam jangka waktu tertentu Sunarso (2010).

Sedangkan menurut Permendagri No. 12/2008, beban kerja adalah besaran pekerjaan yang harus dipikul oleh suatu jabatan atau unit organisasi dan merupakan hasil kali antara volume kerja dan norma waktu. Untuk di PDAM Tirta Moedal Kota Semarang sendiri, beban kerja yang diberikan kepada pegawai terbilang sangat ringan seperti hal nya PNS pada umumnya. Khususnya pada bagian unit IPA yang ada di daerah Kudu dan Semarang Barat yang pekerjaan nya mengecek kesediaan supplay air, dan debit air. Mereka juga diberikan rumah dinas di daerah dekat IPA tersebut agar pengawasan lebih optimal. Bandingkan dengan pegawai di bagian lain yang tidak memiliki rumah dinas. Walaupun dengan sistem kerja shift, para pegawai di bagian pengecekan dan pengawasan IPA sangat senang. Karena tidak perlu membeli rumah dan waktu tempuh tempat kerja tergolong sangat dekat. 


\section{Kesimpulan}

Faktor Utama dalam meningkatkan Kualitas Pelayanan pada PDAM Tirta Moedal Kota Semarang adalah pembuatan Sistem Penyedia Air Minum (SPAM). Jika perusahaan telah memiliki banyak lokasi untuk pengolahan air bersih di Kota Semarang maka permasalahan yang dihadapi PDAM terkait minim nya debit/pasokan air ke pelanggan PDAM akan dapat teratasi. Karena masalah paling utama yang dihadapi PDAM adalah pada waktu musim kemarau/ panas, debit air di Kota Semarang sangat minim. Oleh karena itu maka dibangun lah 3 SPAM di Kota Semarang. Lalu Untuk membangun Kualitas Pelayanan agar selalu baik maka faktor-faktor pembentuk nya antara lain :

\section{a. Kualitas ( Quality )}

Adalah sebuah kata bagi penyedia jasa merupakan sesuatu yang harus dikerjakan dengan baik.

\section{b. Pelayanan ( Service )}

Adalah menolong menyediakan segala apa yang diperlukan orang lainseperti pelanggan atau pembeli.

\section{c. Jasa ( Services )}

Adalah semua tindakan atau kinerja yang dapat ditawarkan satu pihak kepada pihak lain yang pada intinya tidak berwujud dan tidak menghasilkan kepemilikan apapun produksinya dapat atau tidak terkait dengan produk fisik.

\section{d. Perusahaan Daerah ( Regional Company )}

Perusahaan daerah menyebutkan bahwa sifat perusahaan daerah diantaranya adalah memberi jasa, penyelenggaraan kemanfaatan umum, dan memupuk pendapatan

\section{e. Faktor Pendukung Pelayanan ( Service Supporting Factors )}

Adalah faktor-faktor pendukung yang sangat penting yang apabila dari salah satu dari faktor tersebut tidak ada, maka pelayanan akan sangat terasa kurang maksimal. 


\section{f. Faktor penghambat pelayanan (Inhibiting Factors of Service )}

Keseluruhan faktor penghambat tersebut dapat dijadikan perusahaan sebagai alat untuk memperbaiki atau mengurangi kesenjangan yang terjadi antara perusahaan dan pelanggan

\section{g. Sistem Kerja ( Work System )}

Adalah serangkaian dari beberapa pekerjaan yang berbeda kemudian dipadukan untuk menghasilkan suatu benda atau jasa yang menghasilkan pelanggan atau keuntungan perusahaan/organisasi

\section{h. Kualitas Hasil Kerja ( Work Quality Results )}

Dalam mengukur kinerja berdasarkan kualitas dari hasil, dilakukan identifikasi bagaimana pencapaian kualitas pekerjaan yang dilakukan artinya melihat mutu hasil kerja yang didasarkan pada standar yang didasarkan pada standar yang ditetapkan

\section{i. Beban Kerja ( WorkLoad )}

Adalah sekumpulan atau sejumlah kegiatan yang harus diselesaikan oleh suatu unit organisasi atau pemegang jabatan dalam jangka waktu tertentu.

Dengan Adanya Sistem dan penerapan pelayanan dan kinerja yang baik maka terbentuklah Kualitas Pelayanan yang memuaskan bagi pelanggan sebagai suatu konsep yang memiliki andil besar dalam Peningkatan Kualitas Pelayanan di Perusahaan Daerah Air Minum (PDAM) Kota Semarang.

\section{Saran}

Bagi Perusahaan Daerah Air Minum (PDAM) Tirta Moedal Kota Semarang :

1. Diharapkan terus meningkatkan Kualitas Pelayanan terhadap pelanggan pelanggan nya. Sehingga dapat menjadi contoh yang baik kepada BUMD di Kota Semarang.

2. Diharapkan lebih meningkatkan sistem kerja terkait dengan upaya peningkatan Kualitas Pelayanan dengan melakukan pemutakhiran sarana dan prasarana alat-alat produksi guna semakin meningkatkan kepuasan pelanggan. 
3. Diharapkan lebih meningkatkan pelayanan di bidang Custamer Service, pengecekan pipa-pipa dan penanganan cepat terkait keluhan Masyarakat untuk meningkatkan Kualitas Pelayanan kepada Pelanggan PDAM Kota Semarang.

4. Diharapkan terus mempercepat pembangunan Sistem Penyedia Air Minum (SPAM) untuk mengatasi keluhan masyarakat terkait air yang tidak mengalir karena minim nya debit air di Kota Semarang Saat Musim Panas/Kemarau.

5. Diharapkan lebih cepat taggap dalam menanggapi laporan warga yang membutuhkan pasokan Air Bersih saat Musim Panas dengan mengirim mobil air tandon PDAM ke pemukiman pelanggan khususnya daerah Semarang atas ( Banyumanik, Gunung Pati, Mijen )

6. Diharapkan terus mempererat dan mempertahankan hubungan kekeluargaan yang sudah terjalin sangat baik antar para pegawai PDAM dan melakukan Tugas-tugas Kerja sesuai SOP, bekerja dengan penuh tanggung jawab terhadap tugas nya sehingga dapat menjadi contoh BUMD dalam upaya peningkatan Kalitas Pelayanan yang baik di Kota Semarang.

\section{Keterbatasan Penelitian}

Adapun Keterbatasan yang ditemukan dalam penelitian ini adalah minim nya informasi yang didapatkan dari berbagai kator cabang PDAM di Kota Semarang. Dan Peneliti hanya mendapatkan informasi dari kantor melalui Bagian Penelitian dan Pembangunan (LitBang) dikarenakan di bagian itulah pusat segala informasi pengembangan PDAM ada. Tetapi peneliti juga mendapat sumber informasi dari Custamer Service PDAM dan beberapa sosial media yang terus memberikan keluhan nya ke PDAM, sehingga peneliti merasa cukup informasi dalam menyusun Skripsi dan membuat latar belakang masalah. 


\section{Agenda Peneliti yang akan datang}

Agenda Penelitian yang akan dilaksanakan mendatang adalah pada penelitian selanjutnya dapat dipertimbangkan untuk menambah informan agar dapat menambah upaya peningkatan Kualitas Pelayanan yang secara teoritis memiliki pengaruh yang signifikan terhadap kepuasan pelanggan PDAM. Selain itu pertimbangan lain adalah menambah informasi dari kantor cabang PDAM Kota Semarang untuk lebih mendapatkan menambah informasi guna peningkatan hasil penelitian yang dilakukan.

\section{Daftar Pustaka}

Fandy Tjiptono, Gregorius Chandra, 2011, Service, Quality and Satisfaction, edisi 3, Jakarta, Andi

Tracey S. Dagger, Jillian C. Sweeney, Laster W. Johnson ,2007, A Hierarchical Model of Health Service Quality: Scale Development and Investigation of an Integrated Model, journal of service research

Kotler, Philip dan Keller, Kevin Lane, (2013), Marketing Management, 14th Edition, Pearson E

Ratminto dan Atik Septi Winarsih. 2006. Manajemen Pelayanan, Pengembangan Model Konseptual, Penerapan Citizen's Charter dan Standar Pelayanan Minimal. Yogyakarta: Pustaka Pelajar.education Limited.

Moenir.(2000). Manajemen Pelayanan Publik. Jakarta: Bina Aksara.

Yamit, Zulian. 2004. Manajemen Kualitas: Produk dan Jasa. Yogyakarta: Ekonisi

Sulistiyani, Ambar Teguh dan Rosidah .2009. Manajemen Sumber Daya Manusia.

Konsep, Teori dan Pengembangan dalam Konteks Organisasai Publik,

Edisi kedua. Yogyakarta: Graha Ilmu

Sunarso dan Kusdi. 2010. Pengaruh Kepemimpinan, Kedisiplinan,Beban Kerja dan Motivasi Terhadap Kinerja Guru Sekolah Dasar. Jurnal Manajemen SD Fakultas Ekonomi Universitas Slamet Riyadi Surakarta Vol.4 No.1 Juni 2010 : 72-79. 